Article

\title{
Gene Expression Profiling of Corpus luteum Reveals Important Insights about Early Pregnancy in Domestic Sheep
}

\author{
Kisun Pokharel $^{1}{ }^{\circledR}$, Jaana Peippo ${ }^{2}$, Melak Weldenegodguad ${ }^{1}\left(\right.$, Mervi Honkatukia ${ }^{3}$, \\ Meng-Hua $\mathrm{Li}^{4, *}$ and Juha Kantanen ${ }^{2, *(\mathbb{D})}$ \\ 1 Natural Resources, Natural Resources Institute Finland (Luke), 31600 Jokioinen, Finland; \\ kisun.pokharel@luke.fi (K.P.); melak.weldenegodguad@luke.fi (M.W.) \\ 2 Production Systems, Natural Resources Institute Finland (Luke), 31600 Jokioinen, Finland; \\ jaana.peippo@luke.fi \\ 3 NordGen-The Nordic Genetic Resources Center, 1432 Ås, Norway; mervi.honkatukia@nordgen.org \\ 4 College of Animal Science and Technology, China Agricultural University, Beijing 100193, China \\ * Correspondence: menghua.li@cau.edu.cn (M.-H.L.); juha.kantanen@luke.fi (J.K.); \\ Tel.: +358-295-326-210 (J.K.)
}

Received: 2 March 2020; Accepted: 8 April 2020; Published: 10 April 2020

\begin{abstract}
The majority of pregnancy loss in ruminants occurs during the preimplantation stage, which is thus the most critical period determining reproductive success. Here, we performed a comparative transcriptome study by sequencing total mRNA from corpus luteum (CL) collected during the preimplantation stage of pregnancy in Finnsheep, Texel and F1 crosses. A total of 21,287 genes were expressed in our data. Highly expressed autosomal genes in the CL were associated with biological processes such as progesterone formation (STAR, CYP11A1, and HSD3B1) and embryo implantation (e.g., TIMP1, TIMP2 and TCTP). Among the list of differentially expressed genes, sialic acid-binding immunoglobulin (Ig)-like lectins (SIGLEC3, SIGLEC14, SIGLEC8), ribosomal proteins (RPL17, RPL34, RPS3A, MRPS33) and chemokines (CCL5, CCL24, CXCL13, CXCL9) were upregulated in Finnsheep, while four multidrug resistance-associated proteins (MRPs) were upregulated in Texel ewes. A total of 17 known genes and two uncharacterized non-coding RNAs (ncRNAs) were differentially expressed in breed-wise comparisons owing to the flushing diet effect. The significantly upregulated TXNL1 gene indicated potential for embryonic diapause in Finnsheep and F1. Moreover, we report, for the first time in any species, several genes that are active in the CL during early pregnancy (including TXNL1, SIGLEC14, SIGLEC8, MRP4, and CA5A).
\end{abstract}

Keywords: Finnsheep; Texel; progesterone; preimplantation; embryonic diapause

\section{Introduction}

Litter size, a key determinant for the profitability of sheep production systems, is highly dependent on ovulation rate and embryo development in the uterus. Earlier studies have shown that the trait of high prolificacy can result due to the action of either a single gene with a major effect, as in the Chinese $\mathrm{Hu}$, Boorola Merino, Lacaune and small-tailed Han breeds [1-6], or different sets of genes, as in the Finnsheep and Romanov breeds $[7,8]$. The native Finnsheep, one of the most highly prolific breeds, has been exported to more than 40 countries to improve local breeds [9]. In recent years, a FecG ${ }^{\mathrm{F}}(\mathrm{V} 371 \mathrm{M})$ mutation in gene GDF9 has been identified to be strongly associated with litter size in Finnsheep and breeds such as the Norwegian White Sheep, Cambridge and Belclare breeds, which were developed using Finnsheep [10-13]. 
The success of pregnancy establishment in sheep and other domestic ruminants is determined at the preimplantation stage and involves coordination among pregnancy recognition, implantation and placentation, in which the corpus luteum (CL) and endometrium play vital roles [14-16]. The preimplantation stage of pregnancy is the most critical period in determining the litter size because of the high embryo mortality during this period. It has been shown that most embryonic deaths occur before day 18 of pregnancy in sheep [17-19]. Flushing (elevated levels of feed) is known to improve blastocyst yield and embryo survival $[20,21]$. However, due to the biological complexity of the process and to technical difficulties, embryo implantation is still not well understood. The CL is an endocrine structure whose main function is to synthesize and secrete the hormone progesterone. Progesterone production is essential for the establishment of pregnancy. However, if pregnancy is not established, the CL will regress as a result of luteolysis, and a new cycle will begin.

The whole-transcriptome profiling approach enables a deeper understanding of the functions of the $C L$, which may allow the identification of genes and markers that are differentially expressed, for example, between breeds showing different litter size phenotypes. Although most of the studies associated with early pregnancy have been performed in sheep [14,15,22-24], only a few studies have applied transcriptomic approaches to the CL. A microarray-based transcriptomic study conducted identified a number of genes regulated by progesterone (from the $\mathrm{CL}$ ) and interferon tau (IFNT; from the conceptus) in pregnant vs uterine gland knockout (UGKO) ewes [25]. In a more comprehensive study, transcriptome analysis of uterine epithelial cells during the peri-implantation period of pregnancy identified various regulatory pathways and biological processes in sheep [26]. Moore et al. (2016) combined gene expression data with genome-wide association studies (GWASs) to understand the roles of CL and endometrium transcriptomes in dairy cattle fertility [27]. Another study identified differentially expressed genes (DEGs) between Day 4 and Day 11 in the CL in cattle [28]. Though these studies have certainly enhanced our understanding of the roles of the CL during early pregnancy and in ruminant fertility in general, none of these studies conducted specific comparisons between breeds with different reproductive potential. Thus, in this study, a comparison of transcriptome profiles between two breeds (high prolific Finnsheep and low-prolific Texel) was conducted to provide insight into the differences in developmental events in early pregnancy between the breeds. The influence of diet during early pregnancy was assessed by keeping half of the ewes on the flushing diet. Here, the main goal of this study was to build a global picture of transcriptional complexity in $\mathrm{Cl}$ and examine differences in developmental profiles during early pregnancy in sheep breeds showing contrasting fertility phenotypes. Thus, this study has relevance to sheep breeding towards achieving improved reproductive capacity.

\section{Materials and Methods}

\subsection{Experimental Design}

All procedures for the experiment and sheep sampling were approved by the Southern Finland Animal Experiment Committee (approval no. ESAVI/5027/04.10.03/2012). The animals were kept at Pusa Farm in Urjala, located in the province of Western Finland, during the experimental period. A total of 31 ewes representing three breed groups (Finnsheep $(n=11)$, Texel $(n=11)$ and F1 crosses $(n=9)$ were included in the main experiment (please note that only 18 of the 31 ewes have been included in this study) of which approximately half of the ewes from each breed were kept on the flushing diet. Analyses were conducted for two different time points during the establishment of pregnancy: the follicular growth phase [13] and early pregnancy prior to implantation (current study). After ovary removal, the ewes were mated using two Finnsheep rams, and the pregnant ewes were slaughtered during the preimplantation phase of the pregnancy when the embryos were estimated to be one to three weeks old (Table S1). At the slaughterhouse, a set of tissue samples (the pituitary gland, a CL, oviductal and uterine epithelial cells, and preimplantation embryos) were collected and stored in RNAlater reagent (Ambion/Qiagen, Valencia, CA, USA) following the manufacturer's instructions. 
Of the collected tissue samples, CL was subjected to the current study. One of the CLs was dissected from each ovary. For the present study, and particularly for the RNA-Seq of the CL, six ewes each from the Finnsheep, Texel and F1 cross groups were included. Therefore, out of 31 ewes that were originally included in the main experiment, only 18 have been considered here. The experimental design was described in more detail in an earlier study [13].

\subsection{Library Preparation and Sequencing}

RNA was extracted from the tissues using an RNeasy Plus Mini Kit (Qiagen, Valencia, CA, USA) following the manufacturer's protocol. The details on RNA extraction have been described previously [13]. RNA quality (RNA concentration and RNA integrity number) was measured using a Bioanalyzer 2100 (Agilent Technologies, Waldbronn, Germany) before sending the samples to the Finnish Functional Genomics Center, Turku, Finland, where library preparation and sequencing were performed. RNA libraries were prepared according to the Illumina TruSeq®Stranded mRNA Sample Preparation Guide (part \# 15031047) which included poly-A selection step. Unique Illumina TruSeq indexing adapters were ligated to each sample during an adapter ligation step to enable pooling of multiple samples into one flow cell lane. The quality and concentrations of the libraries were assessed with an Agilent Bioanalyzer 2100 (Agilent Technologies Inc., Santa Clara, CA, USA) and by QubitßFluorometric Quantitation (Thermo Fisher Scientific, Waltham, MA, USA), respectively. All samples were normalized and pooled for automated cluster preparation at an Illumina cBot (Illumina Inc., San Diego, CA, USA) station. High-quality libraries of mRNA were sequenced with an Illumina HiSeq 2000 (Illumina Inc., San Diego, CA, USA) instrument using paired-end ( $2 \times 100 \mathrm{bp})$ sequencing strategy.

\subsection{Data Preprocessing and Mapping}

The raw reads were assessed for errors and the presence of adapters using FastQC v0.11.6 [29]. As we noticed the presence of adapters, Trim Galore v0.5.0 [30,31] was used to remove the adapters and low-quality reads and bases. Clean RNA-Seq reads were aligned to the latest sheep reference genome using STAR v2.6.1a [32]. The reference genome (oar_rambouillet_v1.0, BioProject: PRJNA414087) and annotation (NCBI Ovis aries Annotation Release 103) were used to construct "Star genome" prior to mapping step. In order to facilitate the differential expression analysis, the "-quantMode GeneCounts" option was included in the STAR mapping command. Alternatively, we performed transcript quantification under the quasi-mapping-based mode in Salmon v1.1.0 [33] transcriptome index built using oar_rambouillet_v1.0 transcriptome to get TPM (transcripts per million reads) value of expressed genes.

\subsection{Differential Gene Expression Analysis}

The raw counts quantified as part of STAR mapping were considered for gene expression analysis whereas the Salmon-based transcript estimates were summarized to gene level estimates to prepare a table of genes with their abundance using tximport v1.12.3 [34] Bioconductor package. Prior to gene level summarization, a customized "tx2gene" data frame was created using the annotation (.gtf file) of Rambouillet v1.0 transcriptome. We used DESeq2 [35] for differential gene expression analysis. Transcripts with less than 5 read counts were discarded and technical replicates (samples representing same animal) were collapsed/merged before running the DESeq command. Pairwise differential expression analysis was performed between Finnsheep, Texel and F1 crosses. Differentially expressed genes with adjusted p-value of 0.05 (padj < 0.05) and absolute log2(fold change) of 1.5 $($ abs $(\log 2$ FoldChange $)>1.5)$ were regarded as significant in this study. In DESeq2, Benjamini and Hochberg's method is used for estimating the adjusted p-values. For identifying a subset of genes potentially differentially expressed due to flushing diet effect, we employed a separate design by including diet as a secondary factor. The statistical analyses were performed in $\mathrm{R} v$ 3.6.0 [36]. 


\subsection{Functional Analysis of Differentially Expressed Genes}

The ClueGO v2.5.5 [37] plugin in Cytoscape v3.7.0 [38] was employed for gene functional analysis. Prior to performing the analyses, we downloaded the latest versions of the Kyoto Encyclopedia of Genes and Genomes (KEGG) pathways and Gene Ontology (GO) terms. The enrichment analysis was based on a one-sided hypergeometric test with the Benjamini-Hochberg correction method. We used a custom reference set that included a list of all the expressed genes in our data. We also modified the default GO and pathway selection criteria in such a way that a minimum of three genes and four percent of genes from a given GO or KEGG pathway should be present in the query list. Furthermore, GO terms with a minimum level of three and a maximum level of eight were retained. Finally, GO terms and/or KEGG pathways sharing similar genes were grouped together using kappa statistics with kappa score threshold of 0.4 .

\section{Results and Discussion}

\subsection{Phenotypic Observations}

After removal of the remaining ovary, we counted the number of CLs visually in each animal. With an average of 4.1, Finnsheep had the highest number of CLs, whereas Texel had an average of 1.7 CLs (Table 1, Table S1). F1 showed phenotypes closer to those of Finnsheep than those of Texel, having 3.75 CLs on average (Table S1); this was unsurprising, as we observed a similar pattern in an earlier study [13]. We did not observe more than two CLs in the Texel or fewer than three CLs in Finnsheep or F1. Similarly, on average, Finnsheep had the highest number of embryos $(n=2.6)$, followed by F1 crosses $(n=1.8)$ and Texel $(n=1.5)$. Interestingly, the embryo survival rate in Texel was highest, where 1.5 embryos were present from 1.7 CLs $(88 \%)$ on average. On the other hand, Finnsheep (63\%) and F1 cross (48\%) had a remarkably low embryo survival rate. While these findings are based on fewer animals, the results are in agreement with earlier studies $[39,40]$ where typically higher litter size is associated with higher embryo mortality and vice versa. It would be of great interest to determine if productivity follows the same pattern in F2 (i.e., F1 $\times$ F1) crosses, backcrosses and presumably also in a reciprocal cross.

Table 1. Average number of corpus luteum (CL) and embryos in Finnsheep, Texel and their F1 crosses. The full details of the phenotypes are available in Supplementary Table S1.

\begin{tabular}{ccc}
\hline Breed & \# CL & \# Embryos \\
\hline Finnsheep & 4.1 & 2.6 \\
Texel & 1.7 & 1.5 \\
F1 & 3.75 & 1.8 \\
\hline
\end{tabular}

\subsection{RNA-Seq Data}

From the 42 libraries (21 from each tissue, including three technical replicates), around 1104 million (M) raw reads were sequenced, of which $1094 \mathrm{M}$ clean reads were retained after trimming (Table 2). The summary statistics from Trim Galore revealed that up to $3.6 \%$ of the reads were trimmed, with reverse-strand reads having a comparatively higher percentage of trimmed bases. However, the percentage of reads that were excluded for being shorter than $18 \mathrm{bp}$ was always less than $1 \%$ across all samples. More than $80 \%$ of the reads from all samples were aligned to the Rambouillet reference genome and transcriptome using STAR and Salmon, respectively. The raw RNA-Seq data (Fastq files) from this study are available in European Nucleotide Archive (ENA) under project accession code PRJEB32852. The details of sample summary including ENA accession code of individual samples are available in Table 2. 
Table 2. Sample summary. A total of 21 samples with 7 each for Finnsheep (FS), Texel (TX) and F1 crosses of Finnsheep and Texel (F1) were included in this study. Diet is either normal diet (C) or flushing $\operatorname{diet}(\mathrm{F})$. Alignment statistics from STAR include only the uniquely aligned reads whereas those from Salmon include all reads that mapped to reference transcriptome. Numbers for sequence reads are represented as millions $(\mathrm{M})$.

\begin{tabular}{cccccccc}
\hline Sample & Breed & Diet & $\begin{array}{c}\text { Raw } \\
\text { Reads (M) }\end{array}$ & $\begin{array}{c}\text { Clean } \\
\text { Reads (M) }\end{array}$ & $\begin{array}{c}\text { Uniquely } \\
\text { Aligned Reads } \\
\text { (STAR, M) }\end{array}$ & $\begin{array}{c}\text { Aligned Reads } \\
\text { (Salmon, M) }\end{array}$ & $\begin{array}{c}\text { ENA } \\
\text { Accession } \\
\text { Code }\end{array}$ \\
\hline 1033 & TX & C & 56.4 & 55.9 & 48.0 & 50.7 & ERR3349023 \\
107A & TX & F & 55.0 & 54.5 & 46.5 & 49.3 & ERR3349025 \\
$107 \mathrm{~B}$ & TX & F & 55.7 & 55.2 & 48.3 & 49.8 & ERR3349027 \\
251 & TX & F & 41.8 & 41.2 & 35.4 & 36.9 & ERR3349029 \\
302 & TX & C & 54.5 & 54.1 & 47.1 & 48.5 & ERR3349031 \\
$312 \mathrm{~A}$ & FS & F & 54.9 & 54.4 & 47.0 & 49.3 & ERR3349033 \\
$312 B$ & FS & F & 79.2 & 78.4 & 69.2 & 71.1 & ERR3349035 \\
3609 & FS & C & 54.5 & 54.1 & 47.0 & 49.0 & ERR3349037 \\
379 & TX & F & 43.1 & 42.7 & 36.0 & 38.3 & ERR3349039 \\
4208 & F1 & C & 54.3 & 53.8 & 44.8 & 49.0 & ERR3349041 \\
$4271 \mathrm{~A}$ & F1 & F & 47.2 & 46.8 & 40.1 & 42.4 & ERR3349043 \\
$4271 \mathrm{~B}$ & F1 & F & 46.9 & 46.4 & 40.0 & 42.1 & ERR3349045 \\
4519 & F1 & F & 51.6 & 51.1 & 44.5 & 46.3 & ERR3349047 \\
4563 & F1 & F & 54.1 & 53.7 & 45.7 & 48.6 & ERR3349049 \\
4590 & F1 & F & 48.5 & 48.1 & 40.0 & 43.5 & ERR3349051 \\
4823 & F1 & C & 52.6 & 52.1 & 42.6 & 47.2 & ERR3349053 \\
48 & FS & C & 53.4 & 53.0 & 44.7 & 47.9 & ERR3349055 \\
554 & FS & F & 56.0 & 55.5 & 48.1 & 49.7 & ERR3349057 \\
73 & TX & C & 46.1 & 45.7 & 39.1 & 41.3 & ERR3349059 \\
897 & FS & F & 53.3 & 52.9 & 46.1 & 47.9 & ERR3349061 \\
974 & FS & C & 45.1 & 44.7 & 38.6 & 40.4 & ERR3349063 \\
\hline
\end{tabular}

\subsection{Gene Expression in the $C L$}

STAR-based alignment revealed 23,327 genes and pseudogenes expressed in the whole data set which makes up approximately $70 \%$ of the list $(n=33,372)$ available for the recent Rambouillet reference genome. Further grouping of the expressed genes showed that the most genes $(n=21,052)$ were expressed in Finnsheep followed by Texel $(n=20,957)$ and F1 crosses $(n=20,928)$. The cumulative difference in the number of genes in different samples and breeds might be due to transcriptional noise. As shown in Figure 1, the highest number of breed-specific genes was found in Finnsheep $(n=399)$, followed by Texel $(n=363)$ and F1 crosses $(n=303)$. In a pairwise comparison, based on overall gene expression, Finnsheep and F1 crosses shared a higher number of genes $(n=338)$ than other pairs, indicating the closer relatedness of F1 crosses to Finnsheep (Figure 1). As indicated by the principal component analysis (PCA), we did not observe any breed-specific clusters in CL and this was also the case in our earlier ovarian transcriptome study [13]. Alternatively, Salmon-based quantification revealed 27,072 genes expressed in the CL, of which 18,463 had TPM greater than 0.1 (Table S2). 


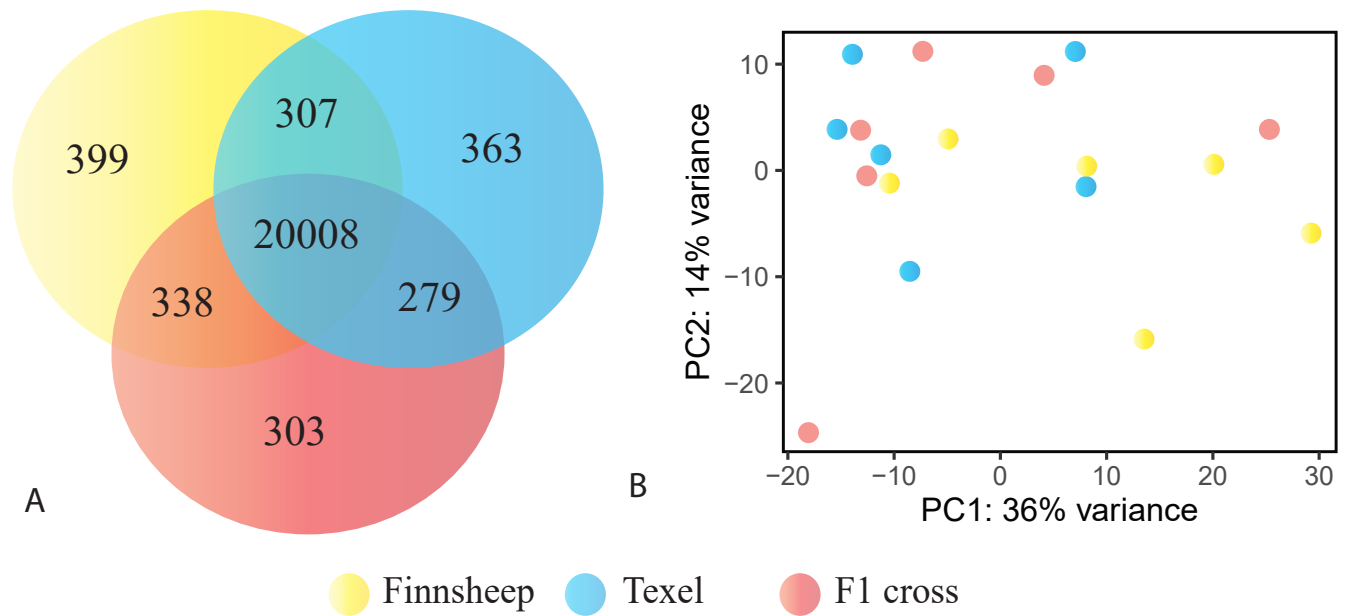

Figure 1. Graphical summary of gene expression in the corpus luteum (CL). (A) Shared and unique genes expressed in the CL of Finnsheep, Texel and their F1. (B) Principal component analysis (PCA) plot based on variance stabilized transformation (VST) of gene expression counts derived from DESeq2 in three breeds.

\subsection{Highly Expressed Genes}

To obtain an overview of the most abundant genes in the tissue, we selected the top 25 genes expressed in the CL (Table 3) derived from Salmon quantification. We noticed that 10 out of the top 25 genes were ribosomal proteins. Moreover, the top expressed genes also appeared to play substantial roles during the preimplantation stage. Steroidogenic acute regulatory protein (STAR), the second most highly expressed gene, plays an important role in mediating the transfer of cholesterol to sites of steroid production [41,42]. Post ovulation, the expression of the majority of genes associated with progesterone synthesis starts to increase and peaks around the late luteal phase, when the CL has fully matured [43-45]. STAR, together with the cytochrome P450 side chain cleavage (P450cc) complex and 3b-hydroxysteroid dehydrogenase/delta5 delta4-isomerase (HSD3B1), are the three most important actors involved in progesterone biosynthesis. STAR is involved in transporting free cholesterol to the inner mitochondrial membrane. The P450cc complex, composed of a cholesterol side chain cleavage enzyme (CYP11A1), ferredoxin reductase (FDXR) and ferredoxin (FDX1), converts the newly arrived cholesterol into pregnenolone [46]. Finally, HSD3B1 helps in converting pregnenolone to progesterone $[45,47-49]$. Three of these major genes involved in progesterone synthesis (STAR, HSD3B1, and HSD3B1) were ranked among the top 25 most highly expressed autosomal genes, while FDX1 $(\mathrm{TPM}=972.8)$ and FDXR $(\mathrm{TPM}=221.5)$ were also highly expressed.

Oxytocin (OXT) was one of the most highly expressed genes in the CL. In cyclic ewes, OXT secreted from the CL and posterior pituitary is widely known to bind with oxytocin receptor $(O X T R)$ from the endometrium to concomitantly release prostaglandin $\mathrm{F}_{2 \alpha}$ (PGF) pulses and induce luteolysis $[15,23,50,51]$. However, for noncyclic ewes, OXT plays an important role during peri-implantation and throughout pregnancy [52]. OXT signaling is known to be influenced by progesterone, but the mechanism underlying the regulation is not yet clear due to conflicting findings [53-56]. Meanwhile OXTR $(\mathrm{TPM}=0.2)$ expression was almost negligible compared to OXT expression. LOC114112617 marked as "uncharacterized ncRNA" is indeed a mitochondrial genome of sheep as blast search of its fasta sequence had 99.9\% sequence similarity (query coverage of $100 \%$ ) to mitochondrial genomes of several sheep breeds, including Finnsheep. Mitochondrial genes are typically abundantly expressed in high-energy demanding tissues and we observed similar expression in ovaries during follicular growth phase [13]. We identified several genes marked as "uncharacterized ncRNA" and those genes should instead be referred to as "uncharacterized contigs". 
Table 3. List of top 25 most abundant genes expressed in the CL. Gene names and gene descriptions for gene IDs starting with "LOC" were retrieved from NCBI Genbank (https://www.ncbi.nlm.nih. gov/genbank/) and, GeneCards (https://www.genecards.org/), respectively. LOC114112617 marked originally as "uncharacterized ncRNA" in NCBI genbank, is indeed the mitochondrial genome of sheep.

\begin{tabular}{|c|c|c|c|}
\hline Gene ID & Gene Description & Chr & Mean TPM \\
\hline TIMP1 & Tissue inhibitor of metallopeptidase 1 & $X$ & 16705.6 \\
\hline STAR & Steroidogenic acute regulatory protein & 26 & 14226.6 \\
\hline OXT & oxytocin/neurophysin I prepropeptide & 13 & 13113.2 \\
\hline MGP & matrix Gla protein & 3 & 12294.0 \\
\hline LOC114112617 & Sheep mitochondrial genome & MT & 12155.9 \\
\hline LOC114113966 & translationally controlled tumour protein $(T C T P)$ & 3 & 8341.7 \\
\hline HSD3B1 & $\begin{array}{l}\text { hydroxy-delta-5-steroid dehydrogenase, } 3 \text { beta- } \\
\text { and steroid delta-isomerase } 1\end{array}$ & 1 & 8249.3 \\
\hline LOC101117785 & Apolipoprotein A1 (APOA1) & 15 & 8213.2 \\
\hline LOC101110773 & elongation factor 1-alpha 1 (EEF1A1) & 10 & 7564.5 \\
\hline LOC101103639 & uncharacterized (protein coding) & 3 & 7272.8 \\
\hline LOC114116158 & thymosin beta- 4 pseudogene & 1 & 6689.3 \\
\hline LOC114118103 & $40 S$ ribosomal protein S29 & 14 & 5599.0 \\
\hline CYP11A1 & $\begin{array}{c}\text { Cytochrome P450 Family } 11 \text { Subfamily A } \\
\text { Member } 1\end{array}$ & 18 & 5096.8 \\
\hline RPLP1 & ribosomal protein lateral stalk subunit P1 & 7 & 5032.2 \\
\hline LOC114116632 & $60 S$ ribosomal protein $\mathrm{L} 23 \mathrm{a}(\mathrm{RPL} 23 a)$ & 10 & 4998.9 \\
\hline FTH1 & Ferritin heavy chain 1 & 21 & 4498.0 \\
\hline RPS8 & ribosomal protein $\mathrm{S} 8$ & 1 & 4402.1 \\
\hline LOC105606567 & $60 S$ ribosomal protein L39 & 4 & 4215.9 \\
\hline$M S M B$ & microseminoprotein beta & 25 & 4093.6 \\
\hline RPS24 & ribosomal protein S24 & 13 & 4029.1 \\
\hline RPS17 & ribosomal protein S17 & 18 & 3950.0 \\
\hline LOC114108766 & $60 S$ ribosomal protein L17 (RPL17) & 4 & 3832.5 \\
\hline RPS18 & ribosomal protein $\mathrm{S} 18$ & 20 & 3657.2 \\
\hline TIMP2 & Tissue inhibitor of metallopeptidase 2 & 11 & 3587.4 \\
\hline LOC114114908 & $40 S$ ribosomal protein S27 (RPS27) & 5 & 3570.4 \\
\hline
\end{tabular}

TPM: Transcripts Per Million, X: chromosome X, MT: Mitochondrial genome.

Two members of tissue-derived matrix metalloproteinase (MMP) inhibitors, also referred to as tissue inhibitors of metallopeptidases (TIMPs), were among the top 25 most abundant genes, of which TIMP1 was ranked number 1 and TIMP2, number 24. In addition to TIMP1 and TIMP2, at least 20 MMPs (including two isoforms of MMP9 and MMP24) two TIMPs, TIMP3 (TPM = 265) and TIMP4 (TPM = 0.5) were expressed in our samples. The high level of TIMPs indicated successful pregnancies, as these inhibitors have low level of expression while their target MMPs are elevated during luteolysis [57-59]. TIMPs have an important role in the regulation of several processes relevant to uterine physiology including angiogenesis [60], cell differentiation [61], and embryo development [62]. Northern blot analyses in several tissues of sheep showed that both TIMP1 and TIMP2 had the greatest abundance in CL during early pregnancy [63]. Moreover, MMPs and TIMPs have important roles in implantation and that the high-level expression of TIMP1 and TIMP2 indicated active invasion of trophoblast cells during implantation $[64,65]$. Another study in bovine oviduct showed that TIMP1 and TIMP2 were highly expressed during the time of ovulation [66]. Hence, these two genes may play significant roles during the whole reproduction process-from ovulation to implantation.

Translationally controlled tumor protein (TCTP) is a highly conserved, multifunctional protein that plays essential roles in development and other biological processes in different species [67-71]. With a maximum level of expression on Day 5 of pregnancy, this protein has been shown to play a significant role in embryo implantation in mice [68]. Consistent with these earlier studies, TCTP appeared to have the highest level of expression during the embryo implantation period. Matrix Gla protein $(M G P)$ is a vitamin K-dependent extracellular matrix protein whose expression has been shown to be correlated with development and maturation processes [72,73] and receptor-mediated adhesion to the extracellular matrix [74]. Several studies have reported that MGP is highly expressed in the 
bovine endometrium $[22,75,76]$ and we have shown that this is also the case with CL. The high level of expression of MGP in our study is consistent with the results of earlier studies in which this gene was found to be elevated during the preimplantation stage in sheep [25,76] and cattle [22]. Similarly, MGP was significantly upregulated in non-regressed compared to regressed bovine CLs [77]. Our data and supporting results from earlier studies on cattle show that MGP is highly expressed in CL during the preimplantation stage and plays important roles in superficial implantation and placentation in sheep.

\subsection{Breed Wise Gene Expression Differences in the CL}

The highest number $(n=133)$ of differentially expressed genes were available for pairwise comparison involving the purebred Finnsheep and Texel (Figure 2, Table S3). Similarly, 31 genes were differentially expressed between Finnsheep and F1 crossbred ewes, of which 19 genes were upregulated in Finnsheep (Table S4). The lowest number $(n=27)$ of DEGs was observed between Texel and F1 crossbred ewes, with two-third genes being upregulated in F1 (Table S5).

Out of the 133 significant DEGs in the CL of pure breeds (i.e., Finnsheep vs. Texel), 90 were upregulated in Finnsheep (Table S3) and the rest were downregulated. About 10\% of the DEGs were uncharacterized ncRNAs indicating the role of non-coding (preferably, long noncoding) RNAs in breed-wise difference during early pregnancy. However, blast search against the non-redundant (NR) database showed that these ncRNAs are possibly contigs spanning one or more genes. In the list of DEGs, we observed a few cases in which more than one gene from the same family was present. Four isoforms of multidrug resistance-associated protein 4-like (MRP4) were upregulated in Texel ewes. Earlier reports have suggested a role of MRP4 in transporting prostaglandins in the endometrium [78], and MRP4 has been found to be upregulated in the endometrium in infertile cows compared to fertile cows [27]. Although there are no reports regarding the existence and roles of MRP4 in the CL, we speculate that the comparatively lower levels of these prostaglandin (PG) transporters in Finnsheep provide a luteoprotective effect. Six sialic acid-binding Ig-like lectins (Siglecs) including three isoforms of SIGLEC-14 were upregulated in Finnsheep. Siglecs are transmembrane molecules expressed on immune cells and mediate inhibitory signaling [79]. So far, SIGLEC-13 has been reported only in nonhuman primates; it was deleted during the course of human evolution [80]. The importance of Siglecs in immune system regulation has been reviewed elsewhere [81]. Siglecs constantly evolve through gene duplication events and may vary between species and even within a species [81-83]. Here, we have reported the expression of Siglecs in CL, which are known to play a role in the immune response during early pregnancy (preimplantation). 


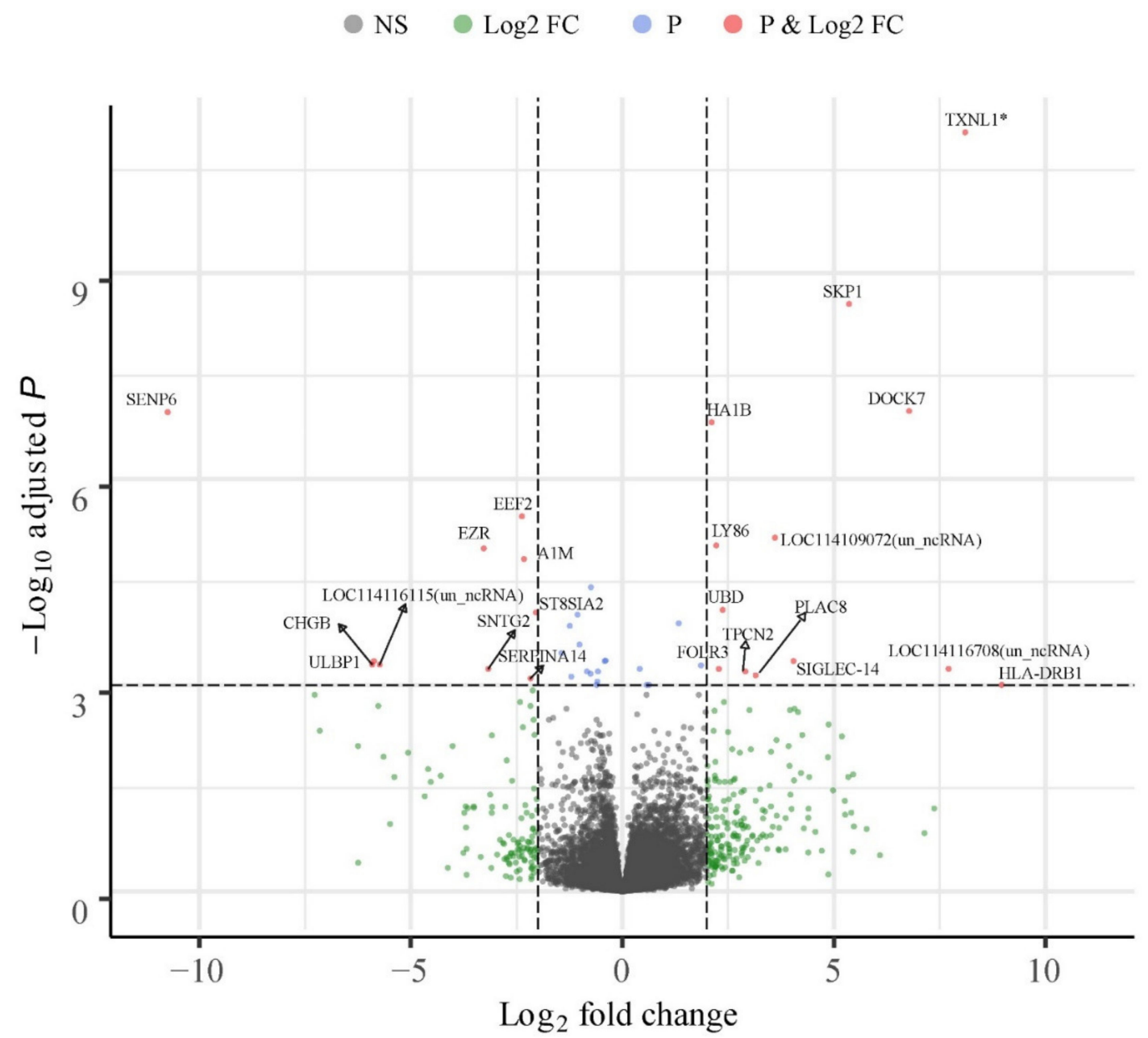

Figure 2. Volcano plot of 23,327 genes expressed in the pure breeds. Top 23 of 133 genes significantly differentially expressed between Finnsheep and Texel are denoted by gene names except three unknown ncRNAs. All DE genes with absolute log2 fold change greater than 2 and adjusted P value lower than 0.001 have been highlighted here. For additional details and complete list of 133 DE genes, please refer Table S3. Note that TXNL1 gene (marked by an asterisk) has an adjusted P-value of 4.84E-16. Volcano plot created using Bioconductor package EnhancedVolcano [84] and some adjustments in the figure were made in Adobe Illustrator (Adobe Inc.). The $\mathrm{x}$-axis represents log2 fold change and the $\mathrm{y}$-axis represents adjusted $p$-values $(-\log 10)$. Legends in top: NS = non-significant; Log2 FC = genes having absolute $\log 2$ fold change greater than $2 ; \mathrm{P}=$ genes with adjusted $P$ value less than $0.001 ;$ and $\mathrm{P} \& \log 2$ FC: genes passing the criteria for $\log 2$ fold change and adjusted $P$ value.

Several cytokines including four chemokines (CCL5, CCL24, CXCL9, and CXCL13), two interleukin receptors (ILIRN, IL12RB1) and two interferons (ISG20, GVINP1) were upregulated in Finnsheep. Other genes with more than one member included major histocompatibility complexes (MHCs) (HA1B, MICB, MICA, BOLA-DQB*0101, etc.), tripartite motif-containing proteins (two isoforms of TRIM5, and TRIM10), cluster of differentiation factors (CD4, CD69), CD300 family molecules (CD300C, and $\mathrm{CD} 300 \mathrm{H})$. Several of the upregulated genes including cytokines and MHCs indicated an enhanced immune system during early pregnancy in Finnsheep compared to Texel. A novel protein coding gene (LOC114116052) was significantly upregulated in Texel. Nucleotide blast search of this novel gene's CDS revealed its sequence similarity with SENP6 in several mammalian species including transcript variants of sheep SENP6 (LOC101118793, 95\% query coverage and 98.7\% sequence identity). Therefore, we concluded that LOC114116052 is one of the isoforms of SENP6. All four ribosomal proteins (MRPS33, RPS3A, RPL17, and RPL34) differentially expressed between the pure breeds were upregulated in 
Finnsheep. Similarly, 16 of the differentially expressed genes were classified as uncharacterized ncRNAs, of which nine were upregulated in Finnsheep. It should be noted, however, that these uncharacterized ncRNAs might include coding genes and thus need further annotation curation.

Out of 90 genes that were significantly upregulated in Finnsheep compared to Texel, 62 were recognized by ClueGO. However, 22 of the recognized genes lacked functional annotation. Thus, enrichment analysis for GO terms and KEGG pathways is based on 40 genes. In the end, only 16 genes passed the selection criteria (see Materials and Methods section) and were associated with 16 representative terms and pathways (Figure 3, Table S6). It turned out that several of the terms and pathways comprised similar genes and grouping based on common genes revealed four different types of terms and/or pathways. The enriched terms and pathways belonged to four main categories based on the way genes were shared. The representative terms and/or pathways associated with upregulated genes were "negative regulation of viral life cycle", "Th1 and Th2 cell differentiation", "chemokine receptor binding" and, "dicarboxylic acid transport". In summary, genes involved in the immune response were upregulated in Finnsheep CL during early pregnancy. Immune-related processes were mainly upregulated in the endometrium of prolific Meishan pig compared to Yorkshire [85]. We speculate that immunity plays bigger role in high prolific Finnsheep compared to Texel during preimplantation.

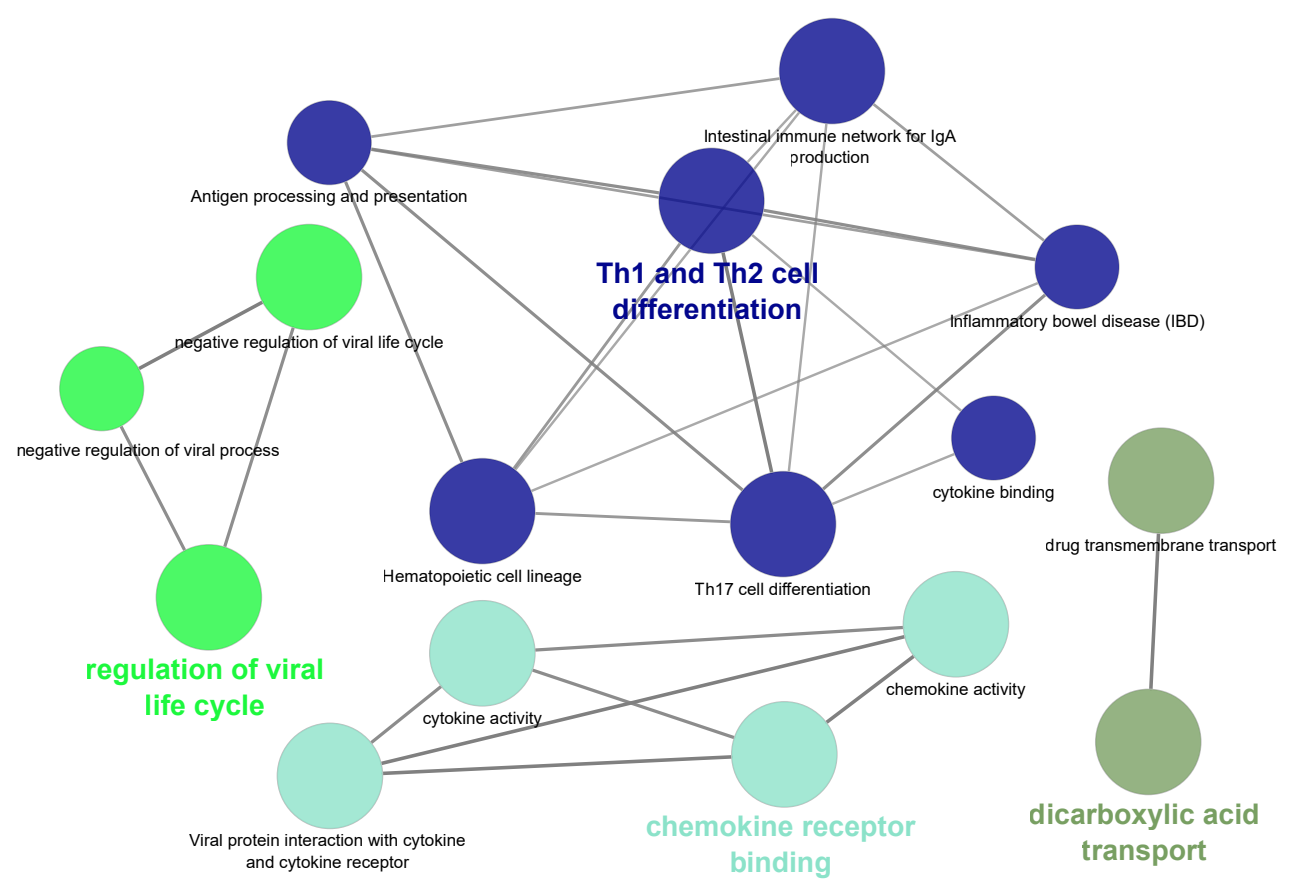

Figure 3. Gene Ontology (GO) terms and Kyoto Encyclopedia of Genes and Genomes (KEGG) pathways associated with significantly differentially expressed genes between Finnsheep and Texel. The functional grouping option in ClueGO categorized 16 GO terms and pathways into four groups using kappa score where the genes shared between the terms are iteratively compared to form functional groups.

\subsection{Uniquely Differentially Expressed Genes}

We noticed that several genes (see Figure 4) were differentially expressed in more than one comparison, increasing our confidence in the identification of these DEGs. Few DEGs were exclusively up- or downregulated in one breed compared to the other two. ANOS1, CLVS2, FOLR3, EEF1A1 and LOC114115287 (uncharacterized ncRNA) were always upregulated in Finnsheep, whereas seven genes were exclusively downregulated. Although LOC114115287 has been marked as an uncharacterized ncRNA, blast search revealed that more than $99 \%$ of its sequence is similar to the sheep mitochondrial genome. This is just another example showing that the gene level annotation of sheep reference 
genome still needs significant improvement. MEPE also was found to be downregulated in Finnsheep during ovulation [13]. SENP6, a protease involved in depolymerization of the small ubiquitin-like modifiers (SUMO-1/2) [86], was the most downregulated gene in Finnsheep compared to both Texel $\left(\log 2\right.$ FoldChange $=-10.7$, padj $=1.07 \times 10^{-7}$, Table S3) and F1 $(\log 2$ FoldChange $=-10.2$, padj $=1.07 \times 10^{-6}$, Table S4). A recent study reported that loss of SENP6 in adult mice led to early embryonic death as well as postnatal premature ageing with skeletal abnormalities [87]. Moreover, knockdown of SENP6 was also linked to upregulated expression of proinflammatory genes [88]. In agreement with our phenotype results (see Table 1) and earlier findings, we speculate that low SENP6 gene expression in Finnsheep is linked to high embryo mortality, and vice versa in the case of Texel.
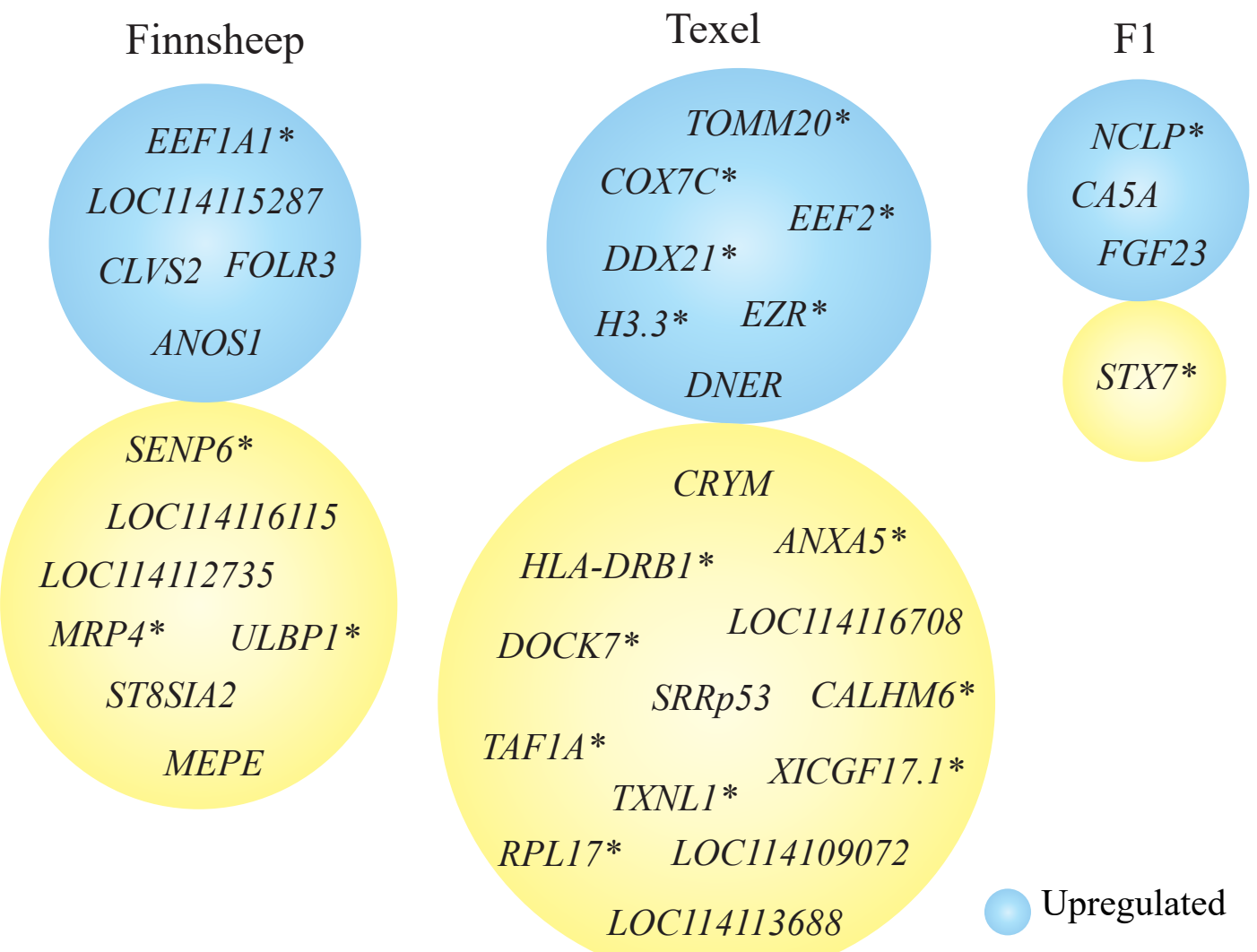

\section{Upregulated}

Downregulated

Figure 4. List of uniquely differentially expressed genes in Finnsheep, Texel and F1. Gene names that were not part of Rambouillet reference transcriptome are marked with an asterisk ${ }^{*}$ ) while gene IDs starting with LOC are "uncharacterized ncRNA".

Seven genes (DNER, LOC106990106 (EZR), LOC114109364 (H3.3), LOC114115573 (COX7C), LOC114115623 (TOMM20) and LOC114115666 (EEF2)) were exclusively upregulated and 13 genes, including three ncRNAs, were exclusively downregulated in Texel (Figure 4). TXNL1 was the most downregulated gene in Texel compared to both Finnsheep $\left(\log 2\right.$ FoldChange $=-9.8$, padj $=6.4 \times 10^{-21}$, Table S3) and F1 ( $\log 2$ FoldChange $=-8.8$, padj $=4.8 \times 10^{-16}$, Table S5). Interestingly, TXNL1 is one of the candidate genes associated with embryonic diapause. Embryonic diapause is an intriguing condition where the embryo development is suspended because of unfavorable conditions for implantation [89]. The environmental conditions, such as food availability, daylight and temperature, and endogenous factors resulting from the ovary, pituitary gland and endometrium have been linked with embryonic diapause [90]. Finnsheep have up to four waves of follicular growth, leading to multiple ovulations [91], and have an extended breeding season [92]. The lambs that were occasionally born any time of the 
year were thought to be due to accidental mating [93,94]. Based on recent findings on the possibility for embryonic diapause to exist across mammals and high level of expression of TXNL1 in our data, Finnsheep have potential for embryonic diapause. In particular, an extended breeding season and out of season breeding might be associated with embryonic diapause. Identification and characterization of other candidate genes in relevant tissues including endometrium in an experimental setting also involving the ewes pregnant for out-of-season breeding is essential for further validation. In addition, similar high-level expression of TXNL1 in F1 cross indicated parent-of-origin effect (POE).

Similarly, CA5A, FGF23 and LOC114109527 (NCLP) were exclusively upregulated in F1 and STX7 was downregulated. Among these, CA5A appeared to be upregulated in F1 crosses compared to both Finnsheep and Texel from both phases (i.e., in the CL in this study and in the ovary in our earlier study). CA5A is a member of the carbonic anhydrase family of zinc-containing metalloenzymes, whose primary function is to catalyze the reversible conversion of carbon dioxide to bicarbonate. The mitochondrial enzyme $C A 5 A$ plays an important role in supplying bicarbonate $\left(\mathrm{HCO}_{3-}\right)$ to numerous other mitochondrial enzymes. In a previous study, we observed downregulation of $C A 5 A$ in the ovaries of Texel compared to F1 [13]. More recently, CA5A was also shown to be expressed in the ovaries of the Pelibuey breed of sheep; the gene was upregulated in a subset of ewes that gave birth to two lambs compared to uniparous animals [95]. However, there are no reports regarding the expression and function of $C A 5 A$ in the CL. Based on the results from our current and earlier reports [13,95], CA5A appears to have an important function, at least until the preimplantation stage of reproduction. The level of expression in F1 crosses in the CL followed the same pattern as that in the ovary, which led us to conclude that $C A 5 A$ is heritable and potentially an imprinted gene. Further experiments are needed to determine whether the gene is associated with high prolificacy.

\subsection{Influence of Flushing in Gene Expression}

Altogether, 19 DEGs including three uncharacterized non-coding RNAs were influenced by the flushing diet. Interestingly, the highest $(n=12)$ number of DEGs was present between the Finnsheep and F1 crosses and the lowest $(n=4)$ number was between the pure breeds (Table 4$)$. Four genes were significantly differentially expressed between Finnsheep and Texel of which three were upregulated in Texel. The only gene upregulated in Finnsheep was cytochrome c oxidase subunit $7 \mathrm{c}$, mitochondrial $(C O X 7 C)$. The three genes significantly upregulated in Texel were PAPPA2, LOC114116073 (ncRNA, uncharacterized) and LOC114118704 (Golgi apparatus membrane protein TVP23 homolog B pseudogene). Out of 12 genes differentially expressed between Finnsheep and F1, five were upregulated in Finnsheep, while seven were upregulated in F1. TVP23 pseudogene was always downregulated in Finnsheep as a result of the flushing diet. Similarly, HOXD10, LOC105611004 (ncRNA, uncharacterized) and LOC114116073 were upregulated in F1 compared to Finnsheep.

An uncharacterized ncRNA (LOC114116073) was strongly downregulated in Finnsheep compared to both Texel $\left(\mathrm{LFC}=-4.6\right.$, padj $\left.=1.26 \times 10^{-28}\right)$ and F1 $\left(\mathrm{LFC}=-4.82\right.$, padj $\left.=5.58 \times 10^{-31}\right)$. The 13,771 nucleotide-long fasta sequence of this uncharacterized ncRNA was queried to nucleotide blast search against NR database. Among the hits, we noticed at least two genes, ULBP1 and NKG2D, among which ULBP1 binds with NKG2D to trigger an immune response [96]. In conclusion, the flushing diet in Texel and F1 crosses led to improved immune surveillance mediated by ULBP1 and NKG2D. Three subsets of homeobox (Hox) genes were upregulated in F1 as a result of flushing diet. HOXD10 and HOXA9 were upregulated against Finnsheep and Texel, respectively, and HOXC11 was upregulated compared to both purebreds. Hox genes are transcriptional factors that precisely regulate embryo development as well as postnatal life. Hox genes are also considered as master regulators due to their role in directing the formation of many body parts. The developmental importance of Hox genes are reviewed elsewhere [97-99]. 
Table 4. List of genes differentially expressed because of the flushing diet in Finnsheep (FS), Texel (TX) and F1 crosses (F1). Gene IDs lacking gene name and/or descriptions (marked with an *) were checked again in the NCBI to retrieve additional information.

\begin{tabular}{cccccc}
\hline Gene & Gene * & Base Mean & LFC & Padj & Condition \\
\hline COX7C & & 101.753584 & 1.93 & 0.03584019 & FS vs. TX \\
LOC114116073 & un_ncRNA & 832.4 & -4.60 & $1.26 \times 10^{-28}$ & FS vs. TX \\
PAPPA2 & & 24.4 & -2.27 & 0.00091 & FS vs. TX \\
LOC114118704 & TVP23(p) & 38.8 & -2.51 & $1.70 \times 10^{-6}$ & FS vs. TX \\
ADAMTS4 & & 892.8 & -1.80 & 0.02409534 & FS vs. F1 \\
SHOX2 & & 74.0 & 1.95 & 0.0200087 & FS vs. F1 \\
HOXD10 & & 99.3 & -2.17 & 0.00279421 & FS vs. F1 \\
SCTR & & 87.9 & 1.70 & 0.0146455 & FS vs. F1 \\
HOXC11 & & 24.1 & -1.81 & 0.01918401 & FS vs. F1 \\
LOC105611004 & un_ncRNA & 40.9 & -2.06 & 0.00279421 & FS vs. F1 \\
LOC114116073 & un_ncRNA & 832.4 & -4.82 & $5.58 \times 10^{-31}$ & FS vs. F1 \\
LRP11 & & 125.0 & -1.84 & 0.02732988 & FS vs. F1 \\
LOC114118704 & TVP23(p) & 38.8 & -1.92 & 0.00279421 & FS vs. F1 \\
BTN1A1 & & 22.4 & 1.86 & 0.02926403 & FS vs. F1 \\
KCNQ1 & & 857.0 & 1.77 & 0.04977007 & FS vs. F1 \\
HNR1PA1 & & 81.1 & 1.93 & 0.0200087 & FS vs. F1 \\
COX7C & & 101.7 & -1.88 & 0.03094773 & TX vs. F1 \\
PCSK5 & & 469.2 & 1.69 & 0.01712337 & TX vs. F1 \\
SCTR & & 87.9 & 1.79 & 0.00816462 & TX vs. F1 \\
HOXC11 & & 24.1 & -1.92 & 0.00816462 & TX vs. F1 \\
PPM1H & & 575.3 & 1.67 & 0.00684851 & TX vs. F1 \\
HOXA9 & & 74.2 & -1.96 & 0.00816462 & TX vs. F1 \\
RDH10 & & 2603.9 & 1.56 & 0.00816462 & TX vs. F1 \\
CA5A & & 983.4 & -1.50 & 0.01137482 & TX vs. F1 \\
\hline
\end{tabular}

LFC: Log2(Fold Change), Padj: Adjusted p-value.

\subsection{Limitations and Thoughts for Future Studies}

We acknowledge certain limitations of this study. With sequencing costs becoming increasingly inexpensive, increasing the sample size of each breed group would certainly add statistical power. Given that time-series experiments are not feasible with the same animal, sampling could be performed with a larger group of animals at different stages of pregnancy to obtain an overview of gene expression changes. The newer Rambouillet reference genome worked better with our data (in terms of alignment and gene expression) compared to Oarv3.1 (data not shown). However, several contigs that are currently marked as "uncharacterized ncRNAs" need to be characterized before the reference genome can be fully utilized. One ovary from each ewe was removed earlier [13] and all the CLs for this study were collected from the remaining ovary. Therefore, there might be some impact due to possible negative feedback effects on overall gene expression. It should be noted that overall gene expression and, more specifically, differential expression between breeds is inherently a stochastic process; thus, there is always some level of bias caused by individual variation [100]. The results from breeding experiments show that productivity traits such as litter sizes may not carry on to F2 crosses $(\mathrm{F} 1 \times \mathrm{F} 1)$ and/or backcrosses. Therefore, future experiments that involve F2 crosses and backcrosses would provide more valuable findings related to prolificacy. Moreover, by doing a reciprocal cross experiment, we might be able to get insight into parent-of-origin effect (POE) and measure the potential contribution of the Texel and Finnsheep in each cross. In addition, replicating such experiments in different environments would be relevant for breeding strategies to mitigate the effects of climate change. To minimize or alleviate noise from tissue heterogeneity, single-cell experiments may prove beneficial in future studies.

\section{Conclusions}

Our phenotypic records indicate lower embryo survival rate in Finnsheep compared to Texel. The relative scarcity of transcriptomic information about the CL means that its functional importance is 
underrated. We identified several key transcripts, including coding genes (producing mRNA) and noncoding genes, that are essential during early pregnancy. Functional analysis primarily based on literature searches and earlier studies revealed the significant roles of the most highly expressed genes in pregnancy recognition, implantation and placentation. F1 crosses were more closely related to Finnsheep than to Texel, as indicated by phenotypic and gene expression results that need to be validated with additional experiments (with F2 and backcrosses). Several genes with potential importance during early pregnancy (including SIGLEC14, SIGLEC8, TXNL1, MRP4, and CA5A) were reported in the CL for the first time in any species. The results from this study show the importance of the immune system during early pregnancy and may even have greater significance to high prolificacy as revealed by significant upregulation of immune-related genes in Finnsheep. Flushing appeared to enhance the immune system and may influence embryo survival. Our results indicate potential for embryonic diapause in sheep and might have an important connection with extended and/or out-of-season breeding in certain breeds of sheep including Finnsheep. We also highlight the need for improved annotation of the sheep genome and emphasize that our data will certainly contribute to such improvement. Taken together, our data provide new information to aid in understanding the complex reproductive events during the preimplantation period in sheep and may also have implications for other ruminants (such as goats and cattle) and mammals, including humans.

Supplementary Materials: The following are available online at http://www.mdpi.com/2073-4425/11/4/415/s1, Table S1: Sheep phenotypes. Extended version of Table 1 that includes additional samples. The last two columns describe the age of embryo (days after mating) and physical appearance of embryo. Table S2: Gene abundance. Mean abundance of expressed derived from salmon based TPM normalization. Genes with TPM $<0.1$ have been excluded in this table. Table S3: Significantly differentially expressed genes between Finnsheep and Texel. Table S4: Significantly differentially expressed genes between Finnsheep and F1. Table S5: Significantly differentially expressed genes between Texel and F1. Table S6: List of GO terms and KEGG pathways associated with significantly upregulated genes in Finnsheep compared to Texel.

Author Contributions: Conceptualization, J.K., and M.-H.L.; methodology, K.P., and M.W.; software, K.P.; formal analysis, K.P.; investigation, K.P.; resources, J.K., M.H., and J.P.; data curation, K.P.; writing—original draft preparation, K.P.; writing — review and editing, K.P., J.P., and J.K; visualization, K.P.; supervision, J.K., and M.-H.L.; project administration, J.K., and M.H.; funding acquisition, J.K., and M.-H.L. All authors have read and agreed to the published version of the manuscript.

Funding: This study was funded by the Academy of Finland (decisions 250633, 250677 and 285017). This study is part of the ClimGen ("Climate Genomics for Farm Animal Adaptation") project funded by FACCE-JPI ERA-NET Plus on Climate Smart Agriculture. K.P. acknowledges financial support from the Niemi Foundation.

Acknowledgments: We are grateful to Anu Tuomola for providing the experimental facilities on her farm in Urjala and to Kati Kaisajoki from Lallin Lammas Ltd. for providing the slaughtering facilities. We thank Johanna Rautiainen, Arja Seppälä, Annukka Numminen, Kalle Saastamoinen, Ilma Tapio, Tuula Marjatta Hamama, Anneli Virta and Magnus Andersson for their valuable assistance during this study. The authors wish to acknowledge the CSC-IT Center for Science, Finland, for computational resources. This study was supported by the Finnish Functional Genomics Centre of the University of Turku, Åbo Akademi and Biocenter Finland.

Conflicts of Interest: The authors declare no conflict of interest. The funders had no role in the design of the study; in the collection, analyses, or interpretation of data; in the writing of the manuscript, or in the decision to publish the results.

\section{References}

1. Davis, G.H.; Farquhar, P.A.; O'Connell, A.R.; Everett-Hincks, J.M.; Wishart, P.J.; Galloway, S.M.; Dodds, K.G. A putative autosomal gene increasing ovulation rate in Romney sheep. Anim. Reprod. Sci. 2006, 92, 65-73. [CrossRef]

2. Davis, G.H.; Galloway, S.M.; Ross, I.K.; Gregan, S.M.; Ward, J.; Nimbkar, B.V.; Ghalsasi, P.M.; Nimbkar, C.; Gray, G.D.; Inounu, I.; et al. DNA tests in prolific sheep from eight countries provide new evidence on origin of the Booroola (FecB) mutation. Biol. Reprod. 2002, 66, 1869-1874. [CrossRef] [PubMed]

3. Chu, M.X.; Mu, Y.L.; Fang, L.; Ye, S.C.; Sun, S.H. Prolactin receptor as a candidate gene for prolificacy of small tail Han sheep. Anim. Biotechnol. 2007, 18, 65-73. [CrossRef] [PubMed] 
4. Drouilhet, L.; Mansanet, C.; Sarry, J.; Tabet, K.; Bardou, P.; Woloszyn, F.; Lluch, J.; Harichaux, G.; Viguié, C.; Monniaux, D.; et al. The highly prolific phenotype of Lacaune sheep is associated with an ectopic expression of the B4GALNT2 gene within the ovary. PLoS Genet. 2013, 9, e1003809. [CrossRef] [PubMed]

5. Mulsant, P.; Lecerf, F.; Fabre, S.; Schibler, L.; Monget, P.; Lanneluc, I.; Pisselet, C.; Riquet, J.; Monniaux, D.; Callebaut, I.; et al. Mutation in bone morphogenetic protein receptor-IB is associated with increased ovulation rate in Booroola Mérino ewes. Proc. Natl. Acad. Sci. USA 2001, 98, 5104-5109. [CrossRef] [PubMed]

6. Souza, C.J.; MacDougall, C.; MacDougall, C.; Campbell, B.K.; McNeilly, A.S.; Baird, D.T. The Booroola (FecB) phenotype is associated with a mutation in the bone morphogenetic receptor type $1 \mathrm{~B}(B M P R 1 B)$ gene. J. Endocrinol. 2001, 169, R1-R6. [CrossRef] [PubMed]

7. Ricordeau, G.; Thimonier, J.; Poivey, J.P.; Driancourt, M.A.; Hochereau-De-Reviers, M.T.; Tchamitchian, L. I.N.R.A. research on the Romanov sheep breed in France: A review. Livest. Prod. Sci. 1990, 24, 305-332. [CrossRef]

8. Xu, S.-S.; Gao, L.; Xie, X.-L.; Ren, Y.-L.; Shen, Z.-Q.; Wang, F.; Shen, M.; Eypórsdóttir, E.; Hallsson, J.H.; Kiseleva, T; et al. Genome-wide association analyses highlight the potential for different genetic mechanisms for litter size among sheep breeds. Front. Genet. 2018, 9, 118. [CrossRef]

9. Hanrahan, J.P.; Quirke, J.F. Contribution of variation in ovulation rate and embryo survival to within breed variation in litter size. In Genetics of Reproduction in Sheep; Land, R.B., Robinson, D.W., Eds.; Butterworth-Heinemann: Oxford, UK, 1984.

10. Hanrahan, J.P.; Gregan, S.M.; Mulsant, P.; Mullen, M.; Davis, G.H.; Powell, R.; Galloway, S.M. Mutations in the genes for oocyte-derived growth factors GDF9 and BMP15 are associated with both increased ovulation rate and sterility in Cambridge and Belclare sheep (Ovis aries). Biol. Reprod. 2004, 70, 900-909. [CrossRef]

11. Mullen, M.P.; Hanrahan, J.P. Direct evidence on the contribution of a missense mutation in GDF9 to variation in ovulation rate of Finnsheep. PLoS ONE 2014, 9, e95251. [CrossRef]

12. Våge, D.I.; Husdal, M.; Kent, M.P.; Klemetsdal, G.; Boman, I.A. A missense mutation in growth differentiation factor 9 (GDF9) is strongly associated with litter size in sheep. BMC Genet. 2013, 14, 1. [CrossRef] [PubMed]

13. Pokharel, K.; Peippo, J.; Honkatukia, M.; Seppälä, A.; Rautiainen, J.; Ghanem, N.; Hamama, T.-M.; Crowe, M.A.; Andersson, M.; Li, M.-H.; et al. Integrated ovarian mRNA and miRNA transcriptome profiling characterizes the genetic basis of prolificacy traits in sheep (Ovis aries). BMC Genomics 2018, 19, 104. [CrossRef] [PubMed]

14. Spencer, T.E.; Johnson, G.A.; Bazer, F.W.; Burghardt, R.C.; Palmarini, M. Pregnancy recognition and conceptus implantation in domestic ruminants: Roles of progesterone, interferons and endogenous retroviruses. Reprod. Fertil. Dev. 2007, 19, 65-78. [CrossRef] [PubMed]

15. Spencer, T.E.; Johnson, G.A.; Bazer, F.W.; Burghardt, R.C. Implantation mechanisms: Insights from the sheep. Reprod. Camb. Engl. 2004, 128, 657-668. [CrossRef]

16. Geisert, R.D.; Morgan, G.L.; Short, E.C.; Zavy, M.T. Endocrine events associated with endometrial function and conceptus development in cattle. Reprod. Fertil. Dev. 1992, 4, 301-305. [CrossRef]

17. Quinlivan, T.D.; Martin, C.A.; Taylor, W.B.; Cairney, I.M. Estimates of pre- and perinatal mortality in the New Zealand Romney Marsh ewe. I. Pre- and perinatal mortality in those ewes that conceived to one service. J. Reprod. Fertil. 1966, 11, 379-390. [CrossRef]

18. Bolet, G. Timing and extent of embryonic mortality in pigs sheep and goats: Genetic variability. In Embryonic Mortality in Farm Animals; Springer: Dordrecht, The Netherlands, 1986; pp. 12-43.

19. Rickard, J.P.; Ryan, G.; Hall, E.; de Graaf, S.P.; Hermes, R. Using transrectal ultrasound to examine the effect of exogenous progesterone on early embryonic loss in sheep. PLoS ONE 2017, 12, e0183659. [CrossRef]

20. Ashworth, C.J.; Toma, L.M.; Hunter, M.G. Nutritional effects on oocyte and embryo development in mammals: Implications for reproductive efficiency and environmental sustainability. Philos. Trans. R. Soc. Lond. B. Biol. Sci. 2009, 364, 3351-3361. [CrossRef]

21. Jindal, R.; Cosgrove, J.R.; Foxcroft, G.R. Progesterone mediates nutritionally induced effects on embryonic survival in gilts. J. Anim. Sci. 1997, 75, 1063-1070. [CrossRef]

22. Mamo, S.; Mehta, J.P.; Forde, N.; McGettigan, P.; Lonergan, P. Conceptus-endometrium crosstalk during maternal recognition of pregnancy in cattle. Biol. Reprod. 2012, 87, 1-9. [CrossRef]

23. Bazer, F.W. Pregnancy recognition signaling mechanisms in ruminants and pigs. J. Anim. Sci. Biotechnol. 2013, 4, 23. [CrossRef] [PubMed] 
24. Raheem, K.A. An insight into maternal recognition of pregnancy in mammalian species. J. Saudi Soc. Agric. Sci. 2017, 16, 1-6. [CrossRef]

25. Gray, C.A.; Abbey, C.A.; Beremand, P.D.; Choi, Y.; Farmer, J.L.; Adelson, D.L.; Thomas, T.L.; Bazer, F.W.; Spencer, T.E. Identification of endometrial genes regulated by early pregnancy, progesterone, and interferon tau in the ovine uterus. Biol. Reprod. 2006, 74, 383-394. [CrossRef] [PubMed]

26. Brooks, K.; Burns, G.W.; Moraes, J.G.N.; Spencer, T.E. Analysis of the uterine epithelial and conceptus transcriptome and luminal fluid proteome during the peri-implantation period of pregnancy in sheep. Biol. Reprod. 2016, 95, 88. [CrossRef]

27. Moore, S.G.; Pryce, J.E.; Hayes, B.J.; Chamberlain, A.J.; Kemper, K.E.; Berry, D.P.; McCabe, M.; Cormican, P.; Lonergan, P.; Fair, T.; et al. Differentially expressed genes in endometrium and corpus luteum of holstein cows selected for high and low fertility are enriched for sequence variants associated with fertility. Biol. Reprod. 2016, 94, 19. [CrossRef]

28. Kfir, S.; Basavaraja, R.; Wigoda, N.; Ben-Dor, S.; Orr, I.; Meidan, R. Genomic profiling of bovine corpus luteum maturation. PLoS ONE 2018, 13, e0194456. [CrossRef]

29. Andrews, S. FastQC 0.11.6; A Quality Control Tool for High Throughput Sequence Data. Babraham Bioinformatics: Cambridge, UK. Available online: http://www.bioinformatics.babraham.ac.uk/projects/fastqc/ (accessed on 18 January 2013).

30. Krueger, F. Trim Galore; Babraham Bioinformatics: Cambridge, UK. Available online: http://www. bioinformatics.babraham.ac.uk/projects/trim_galore/ (accessed on 9 January 2019).

31. Martin, M. Cutadapt removes adapter sequences from high-throughput sequencing reads. EMBnet. journal 2011, 17, 10-12. [CrossRef]

32. Dobin, A.; Davis, C.A.; Schlesinger, F.; Drenkow, J.; Zaleski, C.; Jha, S.; Batut, P.; Chaisson, M.; Gingeras, T.R. STAR: Ultrafast universal RNA-seq aligner. Bioinformatics 2013, 29, 15-21. [CrossRef]

33. Patro, R.; Duggal, G.; Love, M.I.; Irizarry, R.A.; Kingsford, C. Salmon: Fast and bias-aware quantification of transcript expression using dual-phase inference. Nat. Methods 2017, 14, 417-419. [CrossRef]

34. Soneson, C.; Love, M.I.; Robinson, M.D. Differential analyses for RNA-seq: Transcript-level estimates improve gene-level inferences. F1000Research 2016, 4, 1521. [CrossRef]

35. Love, M.I.; Huber, W.; Anders, S. Moderated estimation of fold change and dispersion for RNA-seq data with DESeq2. Genome Biol. 2014, 15, 550. [CrossRef] [PubMed]

36. R Core Team (2019). Available online: https://www.R-project.org/ (accessed on 8 April 2020).

37. Bindea, G.; Mlecnik, B.; Hackl, H.; Charoentong, P.; Tosolini, M.; Kirilovsky, A.; Fridman, W.-H.; Pagès, F.; Trajanoski, Z.; Galon, J. ClueGO: A Cytoscape plug-in to decipher functionally grouped gene ontology and pathway annotation networks. Bioinformatics 2009, 25, 1091-1093. [CrossRef] [PubMed]

38. Shannon, P.; Markiel, A.; Ozier, O.; Baliga, N.S.; Wang, J.T.; Ramage, D.; Amin, N.; Schwikowski, B.; Ideker, T. Cytoscape: A software environment for integrated models of biomolecular interaction networks. Genome Res. 2003, 13, 2498-2504. [CrossRef] [PubMed]

39. Rhind, S.M.; Robinson, J.J.; Fraser, C.; McHattie, I. Ovulation and embryo survival rates and plasma progesterone concentrations of prolific ewes treated with PMSG. J. Reprod. Fertil. 1980, 58, 139-144. [CrossRef] [PubMed]

40. Silva, C.L.A.D.; van den Brand, H.; Laurenssen, B.F.A.; Broekhuijse, M.L.W.J.; Knol, E.F.; Kemp, B.; Soede, N.M. Relationships between ovulation rate and embryonic and placental characteristics in multiparous sows at 35 days of pregnancy. Animal 2016, 10, 1192-1199. [CrossRef]

41. Stocco, D.M. The role of the StAR protein in steroidogenesis: Challenges for the future. J. Endocrinol. 2000, 164, 247-253. [CrossRef]

42. Christenson, L.K.; Devoto, L. Cholesterol transport and steroidogenesis by the corpus luteum. Reprod. Biol. Endocrinol. RBE 2003, 1, 90. [CrossRef]

43. Juengel, J.L.; Meberg, B.M.; Turzillo, A.M.; Nett, T.M.; Niswender, G.D. Hormonal regulation of messenger ribonucleic acid encoding steroidogenic acute regulatory protein in ovine corpora lutea. Endocrinology 1995, 136, 5423-5429. [CrossRef]

44. Devoto, L.; Kohen, P.; Gonzalez, R.R.; Castro, O.; Retamales, I.; Vega, M.; Carvallo, P.; Christenson, L.K.; Strauss, J.F. Expression of steroidogenic acute regulatory protein in the human corpus luteum throughout the luteal phase. J. Clin. Endocrinol. Metab. 2001, 86, 5633-5639. [CrossRef] 
45. Davis, J.S.; LaVoie, H.A. Molecular regulation of progesterone production in the corpus luteum. In The Ovary, 3rd ed.; Academic Press: Cambridge, MA, USA, 2019; ISBN 9780128132098.

46. King, S.R.; LaVoie, H.A. Regulation of the early steps in gonadal steroidogenesis. In Reproductive Endocrinology; Springer: Boston, MA, USA, 2009; pp. 175-193.

47. Hu, J.; Zhang, Z.; Shen, W.-J.; Azhar, S. Cellular cholesterol delivery, intracellular processing and utilization for biosynthesis of steroid hormones. Nutr. Metab. 2010, 7, 47. [CrossRef]

48. Plant, T.M.; Zeleznik, A.J.; Auchus, R.J. Chapter 8-Human steroid biosynthesis. In Knobil and Neill's Physiology of Reproduction; Academic Press: Cambridge, MA, USA, 2015; pp. 295-312, ISBN 9780123971753.

49. Stouffer, R.L.; Hennebold, J.D. Structure, function, and regulation of the corpus luteum. In Knobil and Neill's Physiology of Reproduction; Academic Press: Cambridge, MA, USA, 2015; pp. 1023-1076, ISBN 9780123971753.

50. Spencer, T.E.; Burghardt, R.C.; Johnson, G.A.; Bazer, F.W. Conceptus signals for establishment and maintenance of pregnancy. Anim. Reprod. Sci. 2004, 82-83, 537-550. [CrossRef] [PubMed]

51. Flint, A.P.F.; Sheldrick, E.L. Ovarian oxytocin and the maternal recognition of pregnancy. Reproduction 1986, 76, 831-839. [CrossRef] [PubMed]

52. Kendrick, K.M. Oxytocin, motherhood and bonding. Exp. Physiol. 2000, 85, 111s-124s. [CrossRef] [PubMed]

53. Bishop, C.V. Progesterone inhibition of oxytocin signaling in endometrium. Front. Neurosci. 2013, 7, 138. [CrossRef]

54. Fleming, J.A.G.W.; Spencer, T.E.; Safe, S.H.; Bazer, F.W. Estrogen regulates transcription of the ovine oxytocin receptor gene through GC-rich SP1 promoter elements. Endocrinology 2006, 147, 899-911. [CrossRef]

55. Gimpl, G.; Wiegand, V.; Burger, K.; Fahrenholz, F. Cholesterol and steroid hormones: Modulators of oxytocin receptor function. In Vasopressin and Oxytocin; Elsevier: Amsterdam, The Netherlands, 2002; Volume 139, pp. 43-56.

56. Grazzini, E.; Guillon, G.; Mouillac, B.; Zingg, H.H. Inhibition of oxytocin receptor function by direct binding of progesterone. Nature 1998, 392, 509-512. [CrossRef]

57. Nissi, R.; Talvensaari-Mattila, A.; Kotila, V.; Niinimäki, M.; Järvelä, I.; Turpeenniemi-Hujanen, T. Circulating matrix metalloproteinase MMP-9 and MMP-2/TIMP-2 complex are associated with spontaneous early pregnancy failure. Reprod. Biol. Endocrinol. RBE 2013, 11, 2. [CrossRef]

58. Kliem, H.; Welter, H.; Kraetzl, W.D.; Steffl, M.; Meyer, H.H.D.; Schams, D.; Berisha, B. Expression and localisation of extracellular matrix degrading proteases and their inhibitors during the oestrous cycle and after induced luteolysis in the bovine corpus luteum. Reprod. Camb. Engl. 2007, 134, 535-547. [CrossRef]

59. Curry, T.E.; Osteen, K.G. Cyclic changes in the matrix metalloproteinase system in the ovary and uterus. Biol. Reprod. 2001, 64, 1285-1296. [CrossRef]

60. Moses, M.A.; Sudhalter, J.; Langer, R. Identification of an inhibitor of neovascularization from cartilage. Science 1990, 248, 1408-1410. [CrossRef]

61. Docherty, A.J.; Lyons, A.; Smith, B.J.; Wright, E.M.; Stephens, P.E.; Harris, T.J.; Murphy, G.; Reynolds, J.J. Sequence of human tissue inhibitor of metalloproteinases and its identity to erythroid-potentiating activity. Nature 1985, 318, 66-69. [CrossRef] [PubMed]

62. Nakanishi, Y.; Sugiura, F.; Kishi, J.; Hayakawa, T. Collagenase inhibitor stimulates cleft formation during early morphogenesis of mouse salivary gland. Dev. Biol. 1986, 113, 201-206. [CrossRef]

63. Hampton, A.L.; Butt, A.R.; Riley, S.C.; Salamonsen, L.A. Tissue inhibitors of metalloproteinases in endometrium of ovariectomized steroid-treated ewes and during the estrous cycle and early pregnancy. Biol. Reprod. 1995, 53, 302-311. [CrossRef] [PubMed]

64. Librach, C.L.; Werb, Z.; Fitzgerald, M.L.; Chiu, K.; Corwin, N.M.; Esteves, R.A.; Grobelny, D.; Galardy, R.; Damsky, C.H.; Fisher, S.J. 92-kD type IV collagenase mediates invasion of human cytotrophoblasts. J. Cell Biol. 1991, 113, 437-449. [CrossRef] [PubMed]

65. Bai, S.X.; Wang, Y.L.; Qin, L.; Xiao, Z.J.; Herva, R.; Piao, Y.S. Dynamic expression of matrix metalloproteinases (MMP-2, -9 and -14) and the tissue inhibitors of MMPs (TIMP-1, -2 and -3) at the implantation site during tubal pregnancy. Reproduction 2005, 129, 103-113. [CrossRef] [PubMed]

66. Gabler, C.; Killian, G.J.; Einspanier, R. Differential expression of extracellular matrix components in the bovine oviduct during the oestrous cycle. Reprod. Camb. Engl. 2001, 122, 121-130. [CrossRef]

67. Brioudes, F.; Thierry, A.-M.; Chambrier, P.; Mollereau, B.; Bendahmane, M. Translationally controlled tumor protein is a conserved mitotic growth integrator in animals and plants. Proc. Natl. Acad. Sci. USA 2010, 107, 16384-16389. [CrossRef] [PubMed] 
68. Li, S.; Chen, X.; Ding, Y.; Liu, X.; Wang, Y.; He, J. Expression of translationally controlled tumor protein (TCTP) in the uterus of mice of early pregnancy and its possible significance during embryo implantation. Hum. Reprod. 2011, 26, 2972-2980. [CrossRef] [PubMed]

69. Tuynder, M.; Susini, L.; Prieur, S.; Besse, S.; Fiucci, G.; Amson, R.; Telerman, A. Biological models and genes of tumor reversion: Cellular reprogramming through tpt1/TCTP and SIAH-1. Proc. Natl. Acad. Sci. USA 2002, 99, 14976-14981. [CrossRef]

70. Branco, R.; Masle, J. Systemic signalling through translationally controlled tumour protein controls lateral root formation in Arabidopsis. J. Exp. Bot. 2019, 70, 3927-3940. [CrossRef]

71. Chen, S.H.; Wu, P.-S.; Chou, C.-H.; Yan, Y.-T.; Liu, H.; Weng, S.-Y.; Yang-Yen, H.-F. A knockout mouse approach reveals that TCTP functions as an essential factor for cell proliferation and survival in a tissue- or cell type-specific manner. Mol. Biol. Cell 2007, 18, 2525-2532. [CrossRef] [PubMed]

72. Zhao, J.; Warburton, D. Matrix Gla protein gene expression is induced by transforming growth factor-beta in embryonic lung culture. Am. J. Physiol. Lung Cell. Mol. Physiol. 1997, 273, L282-L287. [CrossRef] [PubMed]

73. Zhao, J.; Nishimoto, S.K. Matrix Gla protein gene expression is elevated during postnatal development. Matrix Biol. J. Int. Soc. Matrix Biol. 1996, 15, 131-140. [CrossRef]

74. Loeser, R.F.; Wallin, R. Cell adhesion to matrix Gla protein and its inhibition by an Arg-Gly-Asp-containing peptide. J. Biol. Chem. 1992, 267, 9459-9462.

75. Forde, N.; Mehta, J.P.; McGettigan, P.A.; Mamo, S.; Bazer, F.W.; Spencer, T.E.; Lonergan, P. Alterations in expression of endometrial genes coding for proteins secreted into the uterine lumen during conceptus elongation in cattle. BMC Genomics 2013, 14, 321. [CrossRef]

76. Spencer, T.E.; Stagg, A.G.; Joyce, M.M.; Jenster, G.; Wood, C.G.; Bazer, F.W.; Wiley, A.A.; Bartol, F.F. Discovery and characterization of endometrial epithelial messenger ribonucleic acids using the ovine uterine gland knockout model. Endocrinology 1999, 140, 4070-4080. [CrossRef]

77. Casey, O.M.; Morris, D.G.; Powell, R.; Sreenan, J.M.; Fitzpatrick, R. Analysis of gene expression in non-regressed and regressed bovine corpus luteum tissue using a customized ovarian cDNA array. Theriogenology 2005, 64, 1963-1976. [CrossRef]

78. Lacroix-Pépin, N.; Danyod, G.; Krishnaswamy, N.; Mondal, S.; Rong, P.-M.; Chapdelaine, P.; Fortier, M.A. The multidrug resistance-associated protein 4 (MRP4) appears as a functional carrier of prostaglandins regulated by oxytocin in the bovine endometrium. Endocrinology 2011, 152, 4993-5004. [CrossRef]

79. Varki, A.; Angata, T. Siglecs-The major subfamily of I-type lectins. Glycobiology 2006, 16, 1R-27R. [CrossRef]

80. Angata, T.; Margulies, E.H.; Green, E.D.; Varki, A. Large-scale sequencing of the CD33-related Siglec gene cluster in five mammalian species reveals rapid evolution by multiple mechanisms. Proc. Natl. Acad. Sci. USA 2004, 101, 13251-13256. [CrossRef]

81. Pillai, S.; Netravali, I.A.; Cariappa, A.; Mattoo, H. Siglecs and immune regulation. Annu. Rev. Immunol. 2012, 30, 357-392. [CrossRef] [PubMed]

82. Bornhöfft, K.F.; Goldammer, T.; Rebl, A.; Galuska, S.P. Siglecs: A journey through the evolution of sialic acid-binding immunoglobulin-type lectins. Dev. Comp. Immunol. 2018, 86, 219-231. [CrossRef] [PubMed]

83. Cao, H.; Crocker, P.R. Evolution of CD33-related siglecs: Regulating host immune functions and escaping pathogen exploitation? Immunology 2011, 132, 18-26. [CrossRef] [PubMed]

84. Blighe, K.; Rana, S.; Lewis, M. EnhancedVolcano: Publication-Ready Volcano Plots with Enhanced Colouring and Labeling; GitHub: San Francisco, CA, USA, 2019.

85. Gu, T.; Zhu, M.; Schroyen, M.; Qu, L.; Nettleton, D.; Kuhar, D.; Lunney, J.K.; Ross, J.W.; Zhao, S.; Tuggle, C.K. Endometrial gene expression profiling in pregnant Meishan and Yorkshire pigs on day 12 of gestation. BMC Genomics 2014, 15, 156. [CrossRef]

86. Tatham, M.H.; Jaffray, E.; Vaughan, O.A.; Desterro, J.M.P.; Botting, C.H.; Naismith, J.H.; Hay, R.T. Polymeric chains of SUMO-2 and SUMO-3 are conjugated to protein substrates by SAE1/SAE2 and Ubc9. J. Biol. Chem. 2001, 276, 35368-35374. [CrossRef]

87. Li, J.; Lu, D.; Dou, H.; Liu, H.; Weaver, K.; Wang, W.; Li, J.; Yeh, E.T.H.; Williams, B.O.; Zheng, L.; et al. Desumoylase SENP6 maintains osteochondroprogenitor homeostasis by suppressing the p53 pathway. Nat. Commun. 2018, 9, 1-14. [CrossRef]

88. Liu, X.; Chen, W.; Wang, Q.; Li, L.; Wang, C. Negative regulation of TLR inflammatory signaling by the SUMO-deconjugating enzyme SENP6. PLOS Pathog. 2013, 9, e1003480. [CrossRef]

89. Renfree, M.B.; Shaw, G. Diapause. Annu. Rev. Physiol. 2000, 62, 353-375. [CrossRef] 
90. Lopes, F.L.; Desmarais, J.A.; Murphy, B.D. Embryonic diapause and its regulation. Reproduction 2004, 128, 669-678. [CrossRef]

91. Bartlewski, P.M.; Beard, A.P.; Cook, S.J.; Chandolia, R.K.; Honaramooz, A.; Rawlings, N.C. Ovarian antral follicular dynamics and their relationships with endocrine variables throughout the oestrous cycle in breeds of sheep differing in prolificacy. Reproduction 1999, 115, 111-124. [CrossRef]

92. Maijala, K. Review of experience about the use of Finnsheep in improving fertility. In Proceedings of the 2nd World Congress on Sheep and Beef Cattle Breeding, Pretoria, South Africa, 16-19 April 1984; pp. 519-531.

93. Maijala, K.; Kangasniemi, R. Experiences of out-of-season and twice-a-year lambings in Finnsheep. World Rev. Anim. Prod. 1972, 8, 84.

94. Österberg, S. Breeding season of the Finnsheep ewe. Acta Agric. Scand. 1981, 31, 11-16. [CrossRef]

95. Hernández-Montiel, W.; Collí-Dula, R.C.; Ramón-Ugalde, J.P.; Martínez-Núñez, M.A.; Zamora-Bustillos, R. RNA-seq transcriptome analysis in ovarian tissue of Pelibuey breed to explore the regulation of prolificacy. Genes 2019, 10, 358. [CrossRef] [PubMed]

96. Sutherland, C.L.; Chalupny, N.J.; Schooley, K.; VandenBos, T.; Kubin, M.; Cosman, D. UL16-binding proteins, novel MHC class I-related proteins, bind to NKG2D and activate multiple signaling pathways in primary NK cells. J. Immunol. 2002, 168, 671-679. [CrossRef]

97. Daftary, G.S.; Taylor, H.S. Endocrine regulation of HOX genes. Endocr. Rev. 2006, 27, 331-355. [CrossRef] [PubMed]

98. Lappin, T.R.; Grier, D.G.; Thompson, A.; Halliday, H.L. HOX genes: Seductive science, mysterious mechanisms. Ulster Med. J. 2006, 75, 23-31. [PubMed]

99. Mallo, M.; Alonso, C.R. The regulation of Hox gene expression during animal development. Development 2013, 140, 3951-3963. [CrossRef] [PubMed]

100. Hansen, K.D.; Wu, Z.; Irizarry, R.A.; Leek, J.T. Sequencing technology does not eliminate biological variability. Nat. Biotechnol. 2011, 29, 572-573. [CrossRef] [PubMed]

(C) 2020 by the authors. Licensee MDPI, Basel, Switzerland. This article is an open access article distributed under the terms and conditions of the Creative Commons Attribution (CC BY) license (http://creativecommons.org/licenses/by/4.0/). 